\title{
210 衝撃波の回折と反射に関する可視化
}

高藤亮一*，山中昭央*，小原哲郎**，大八木重治**

\section{A Visualization on the Diffraction and Reflection Process of Shock Wave}

\author{
Ryouichi TAKAFUJI, Akio YAMANAKA, \\ Tetsuro OBARA, Shigeharu OHYAGI
}

\begin{abstract}
It is important to investigate a pressure profile when a shock wave interacts with a reflector from a safety point of view. In this study, experiments are carried out using a shock tube of $50 \mathrm{~mm}$ diameter and $8 \mathrm{~m}$ in total length with a cylindrical reflector of $50 \mathrm{~mm}$ in the observation section. The behavior of reflection process of diffracted shock wave is visualized with the aid of Schlieren techniques. As a result, (i) a pressure histories on the reflector coincides between numerical and experimental results. (ii) The sequential flow-field behind the shock wave is clearified. (iii) An empirical formula of maximum pressure is obtained with a parameter of a energy pen unit area.
\end{abstract}

Keywords: Shock wave, Schlieren method, Numerical simulation

\section{1 はじめに}

火山の噴火による爆風や、ロケット打ち上げ施設で の爆発事故などでは、球状に広がる衝撃波が発生し、 周囲に甚大な被害を及ぼす。このような被害を最小限 にするため、爆発物の周囲で建物が建てられる場所で は、衝撃波が到達したときの被害予测に基づいた安全 距離が設定されている。ところが、爆発点から被害を 及ぼす建物までの地形などにより、圧力の履歴が変化 するため、その挙動の予測は困難である $[1]$ 。

これまでに地形の変化による衝撃波の挙動予測が、3 次元の数值シュミレーションなどにより行われてきた [2],[3]。また、渦輪と衝撃波の干涉により発生する散乱 波は、音波となって騒音の原因となる。この挙動を調 べるため、円形管から放出される衝撃波の背後に生ず る渦と、壁面で反射した衝撃波がその背後流れと干渉 寸る様子が観察されている [4],[5]。

本研究では、開放端の前方に円筒形の反射体を設置 し、回折した衝軗波を干涉させ、その際の挙動につい てシュリーレン法により可視化した。また、反射体前 面の圧力履歴を詳細に調べ、それを明らかにしたので 報告する。

\section{2 実験装置および方法}

Fig.1に実験装置の概略を示す。実験に用いたのは無 隔膜型衝撃波管で、衝撃波管の長さは $4200 \mathrm{~mm}$ 、管の 内径は $50 \mathrm{~mm}$ である。衝撃波管の管端には内径 $25 \mathrm{~mm}$ の開放端が取り付けてある。開放端の駆動管側の端は、 角を鋭角にしたクッキーカッター形状をしており、こ の部分で衝撃波面は切り取られる。また、観測部内に

\footnotetext{
*非会員 埼玉大学大学院

**正会員 埼玉大学工学部
}

は、外径 $50 \mathrm{~mm}$ の円筒形の反射体を開放端の中心軸上 に設置した。この反射体前面中央には圧力変換器 (PCB 113A24) が取り付けてある。これにより、反射体にか かる圧力を測定した。

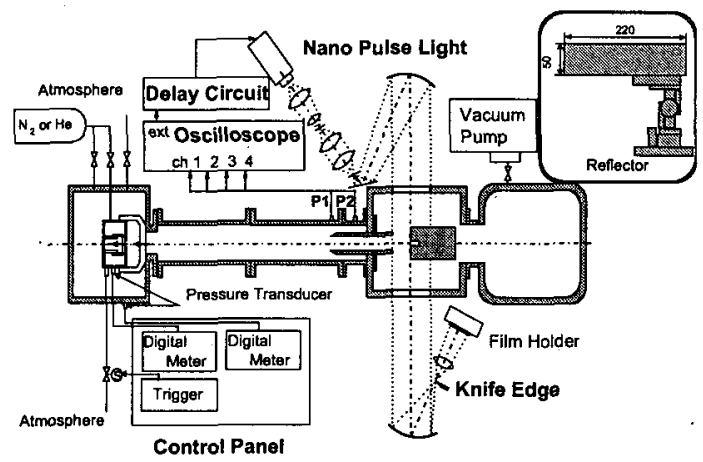

Fig. 1: Schematic diagram of experimental set-up

貯気槽内の駆動気体は、MO バルブ [6] と呼ばれる 2 つのピストンを組み合わせた急速開口弁により、衝撃 波管と隔てられている。また衝撃波管には、反射体に 設置したものと同じ圧力変換器が 2 つ取り付けられて いる。すべての圧力変換器からの信号㤃オシロスコー プに取り込まれ、衝撃波のマッ八数は、衝撃波管に設

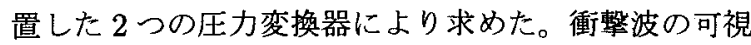
化にはシュリーレン光学系を用いた。光源には発光時 間が $180 \mathrm{~ns}$ のキセノ管を用いた。光源から出た光を 点光源にするため、ピンホール 2 枚とコンデンサーレ ンズを組み合わせた光学系となっている。写真は、反 射体に取り付けられた圧力変換器の立ち上がりをトリ ガ信号として、適当な遅れ時間を決め、衝撃波が反射 
体入射後、任意の時間で撮影した。撮影に用いたフィ ルムは、ISO400のモノクロフィルムである。

Table 1 に実験条件を示す。被駆動気体は空気であ り、貯気槽には駆動気体である窒素またはへリウムを 充填する。開放端と反射体の距離は $50 \mathrm{~mm}$ とし、衝撃 波マッ八数を1.3 2.2の範囲で変化させた。ただし、 マッハ数が 2 以上の条件では駆動気体にヘリウムを用 いた。

Table. 1: Experimental conditions.

\begin{tabular}{lcc}
\hline Driver Gas & $\mathrm{N}_{2}$ & $\mathrm{He}$ \\
\hline Mach Number & $1.3,1.6$ & 2.2 \\
Pressure Ratio & $22.6 \sim 100$ & 40 \\
Driver Pressure (kPa) & $648.5 \sim 1347.6$ & 851.1 \\
Driven Pressure (kPa) & $41.3 \sim 11.3$ & 8.4 \\
\hline
\end{tabular}

\section{3 計算方法}

計算を行うにあたり、以下の仮定をおいた。

1. 流れ場は軸対称とする。

2. 気体は比熱比一定の理想気体とする。

3. 粘性、熱伝導、搪散は無視寸る。

これらの仮定のもとに定式化される基礎方程式を、Explicit Predictor-Corrector TVD スキームを用いて計 算した [7]。計算格子は正方形で格子点数は $500 \times 500$ である。試験気体は空気で、被駆動側圧力を実験条件 と同じにした。

初期衝撃波マッ八数は $M_{S}=1.3,1.6,2.2$ の 3 条件 である。衝撃波は、開放端から $5 \mathrm{~mm}$ 上流側に置いた。 計算領域の大きさは $100 \mathrm{~mm} \times 100 \mathrm{~mm}$ である。境界条 件は、壁面および中心軸に反射条件、その他は、自由 境界条件を用いた。

計算にはワークステーション (DEC, Alpha Station 500/500) を用い、出力された結果をパソコン上で画像 やグラフにした。

\section{4 結果および考察}

\section{1 衝撃波マッハ数 $M_{S}=1.3$ の場合}

Fig. 2 に、マッ八数 $M_{S}=1.3$ の場合に得られた反射 体前面の圧力履歴の実験の結果と数値計算の結果を示 す。実線は実験で得られた圧力波形であり、破線は数值 計算結果である。横軸は衝撃波が反射体と干渉してか らの経過時間である。また Fig.3 は、Fig.2 上の点 $\mathrm{a} \sim \mathrm{d}$ における現象の可視化の結果である。写真上側は、数 值計算によるシュリーレン画像に速度ベクトル線図を 重ねたもので、下側は、奏験で得られたシュリーレン 写真である。回折した衝撃波が反射体で反射すると、 反射衝撃波は、反射体角部で再び回折する (Fig.3a)。 Fig.2a bにかけてこの反射衝繋波の波面を回折させ る膨張波領域は、次第に中心軸方向へ広がり、中心軸 へ達すると膨張波が反射体に接するまでわずかに圧力 が上昇し、その後、圧力の減少を引き起こす (Fig.3b)。 反射した衝撃波が、開放端角部より発生する渦輪に 当たると、衝撃波は大きく回折し、再び反射体の方向 へ伝播する。この衝撃波が反射体と干涉すると、b点 前後におう汁る圧力の立ち上がりを生じる。その後、衝 撃波は中心軸上で互いに反射し減衰する (Fig.3c)。

渦輪が反射体に接近するにつれ、渦輪内部の膨張波 領域により反射体方向への流れが加速され、次第に圧 力が上昇し、 $\mathrm{c}$ 点を過ぎると、压力波形の最初の立ち 上がり、開放端からの衝撃波が反射した際の圧力の 2 倍近くの值になる (Fig.3d)。さらに渦輪が反射体に接 近すると、渦輪の流れに沿って、反射体から離れる方 向の速度が加速され、反射体前面の中央付近での流れ は减速し、流れがよどむ範囲が広がり、圧力は下がり はじめる。

\section{2 衝熬波マッハ数 $M_{S}=1.6$ の場合}

Fig. 4 に、マッ八数 $M_{S}=1.6$ の場合に得られた反射 体前面の圧力波形を示す。マッ八数が $M_{S}=1.3$ の場合 と異なり、渦輪はその中心から発生している 2 次衝撃 波を伴って反射体へ接近する。瀜輸が反射体に接近す るにつれ、瀜輪内部の膨張波領域により反射体方向人 の流れが加速され、圧力が上昇している。

渦輪付近では、渦を取り巻く流れに沿ってすべり線 が発生する。Fig.4のa点での圧力の减少は、このす心 り線が反射体に接近したところで起こっており、反射 体方向に進む流れが、すべり線に沿う流れにより反射 体から離れる方へ、流れの方向が変えられたことによ ると考えられる(Fig.5a)。その後さらに渦輪が反射体 に接近すると、再び圧力は上昇する。渦輪が反射体の わきへ流れ出すと、その流れと反射体前面の流れ場の 境界は滑り線となり、大きな渦列が発生する。これに より、反射体方向への速度は减少し、Fig.4のb点を過 ぎると反射体前面の圧力は減少する (Fig.5b)。

\section{3 衝撃波マッハ数 $M_{S}=2.2$ の場合}

Fig.6に、マッ八数 $M_{S}=2.2$ の場合に得られた反射 体前面の圧力波形を示す。Fig.6の a 点前後で圧力波 形は他の条件とは異なり、圧力がなだらかに減少して いる (Fig.7a)。これは、開放端からの衝撃波の背後の 流れの速度が高く反射体前面でよどむためと考えられ る。その後、Fig.6のb点で、2 次衝撃波を伴う渦輪が 反射体一衝突するが、反射体前面での圧力の降下は小 さく、その後ほぼ一定の値となる (Fig.7b)。

\section{4 最高圧カとマッハ数の関係}

開放端から放出された衝撃波が反射した際の反射衝 撃波背後の压力 $P_{\text {max }}$ は保安距離を設定する上で最も 重要なパラメータであると考えられる。しかしながら、 $P_{\text {max }}$ は衝撃波マッ八数 $M$ 、開放端から反射体までの 距離 $L$ 、開放端の口径 $D$ 、初期圧 $P_{0}$ の関数であり複雑 である。これらの初期条件の違いによらず $P_{\max }$ を予 測することは安全工学上において重要である。Fig.8は 横軸に衝撃波マッ八数 $M$ 、縦軸に $P_{\max } L$ を $P_{0} D$ で無 次元化した值 $\varepsilon$ 示す。無次元量 $\varepsilon$ の物理的意味は単位 面積あたりのエネルギ量である。これよりには、開放端 から反射体までの距離によらずにマッ八数の一次関数 で表されることが分かる。従って $P_{\max }$ は衝撃波マッハ 
数が $1.3 \sim 2.8$ の範囲において次式で与えられる。

$$
P_{\max }=\alpha \frac{D P_{0}}{L}(M-1)
$$

\section{参考文献}

$P_{\text {max }}$ は反射衝撃波背後の圧力であるため、反射体の形 状には依存しない。係数 $\alpha$ は Fig. 8 より $\alpha \simeq 7.1$ と見積 もられる。上式より垂直衝撃波が 3 次元空間へ開放さ れた場合の最高圧力 $P_{\text {max }}$ を精度約 $95 \%$ で見積もるこ とができる。

\section{5 まとめ}

開放端から回折した際の衝撃波の挙動について調べ 以下の知見を得た。

1. 反射体前面における圧力波形について実験と数值 計算結果で比較し良好な一致を得た。

2. 衝撃波マッ八数の違いによる流れ場の差異につい て数值シュリーレン画像および速度ベクトル線図 を用いて明らかにした。

3. 単位面積あたりのエネルギー量はマッハ数の一次 関数で表されることが明らかにされ、この結果は 保安距離を設定する上で重要な基礎データとなり うる。

今後は、開放端内部に溝を設けることにより衝撃波を 減衰させ、溝の数や大きさと、衝撃波の減衰の度合い の関係を調べる予定である。

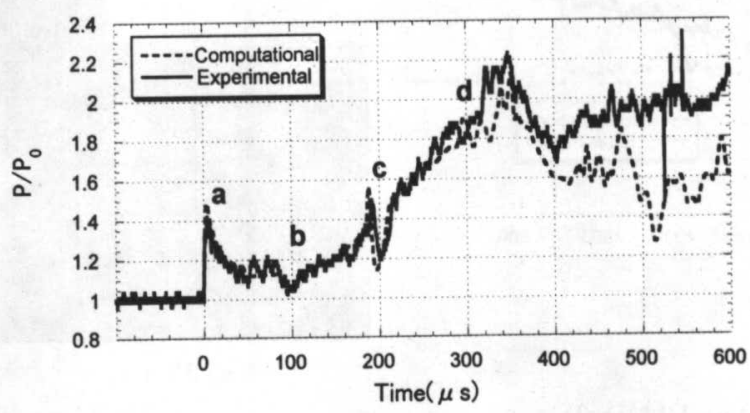

Fig.2 Pressure Profile

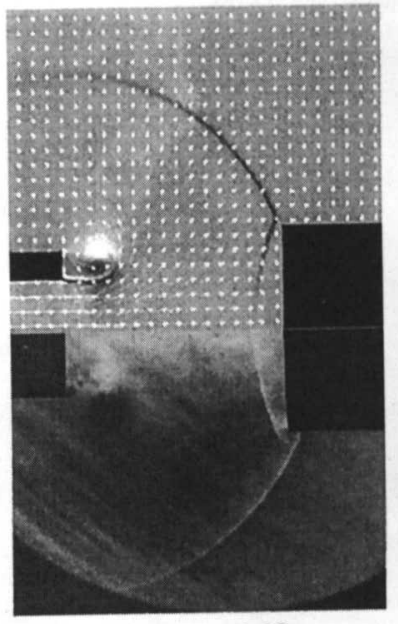

a) $20 \mu \mathrm{s}$

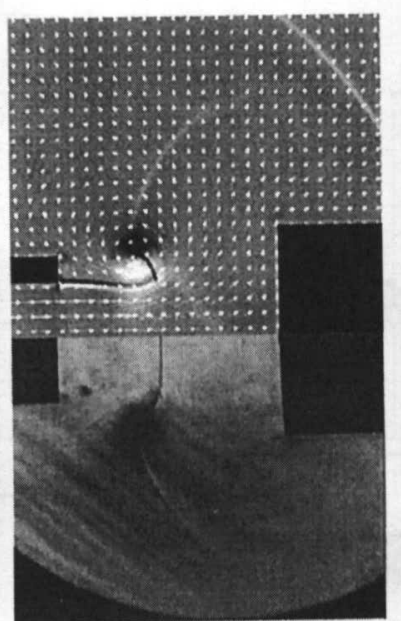

b) $100 \mu \mathrm{s}$

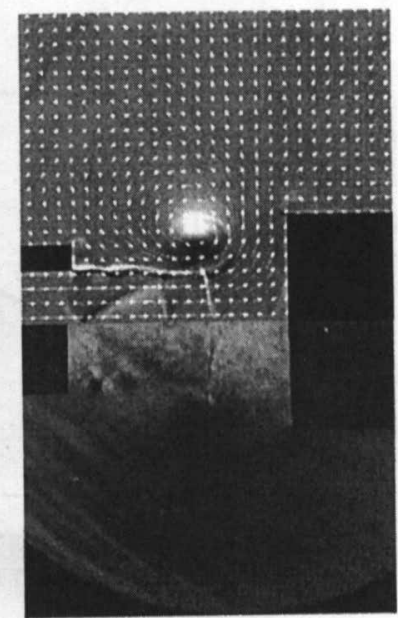

c) $200 \mu \mathrm{s}$

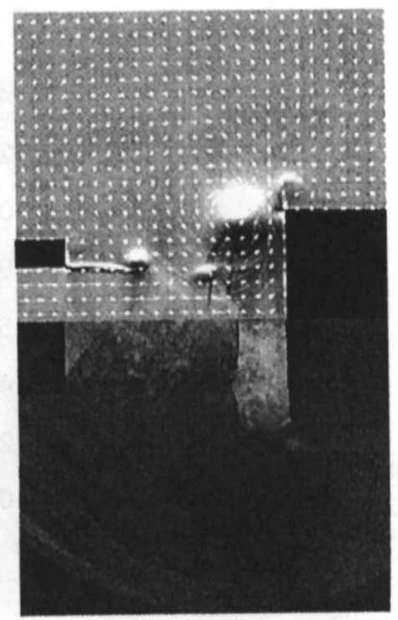

d) $300 \mu \mathrm{s}$

Fig. 3 Numerical velocity vector and calculated and experimental Schlieren photograph $(\mathrm{Ms}=1.3 \mathrm{~L} / \mathrm{D}=2)$ 


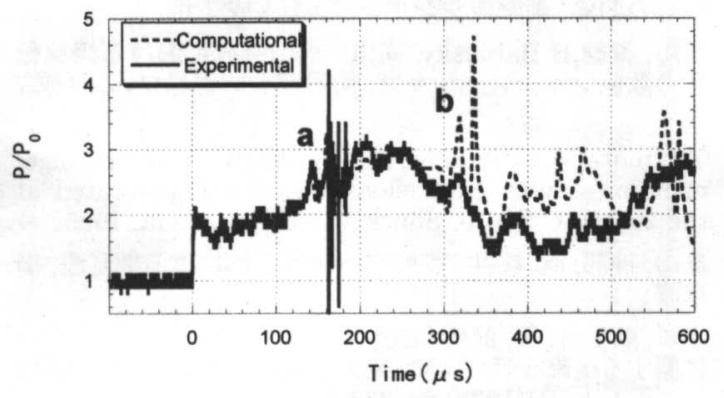

Fig.4 Pressure profile $(\mathrm{Ms}=1.6 \mathrm{~L} / \mathrm{D}=2)$

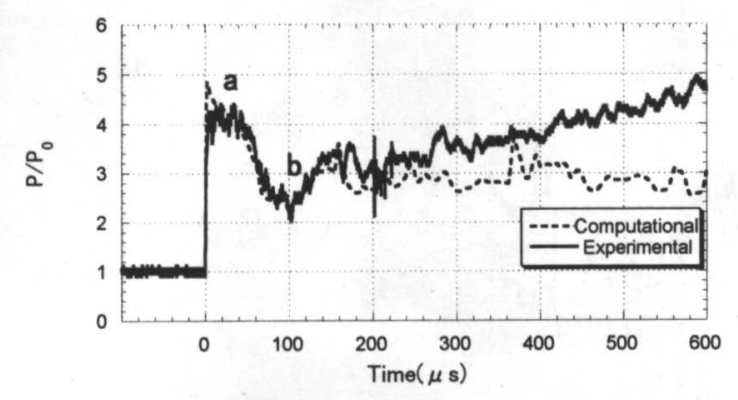

Fig. 6 Pressure profile $(M s=2.2 \mathrm{~L} \backslash \mathrm{D}=2)$

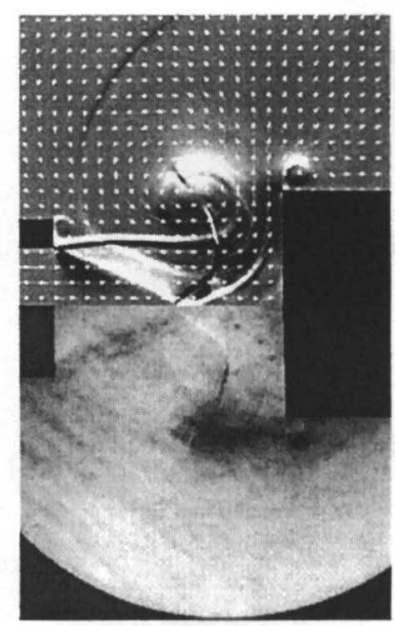

a) $140 \mu \mathrm{s}$

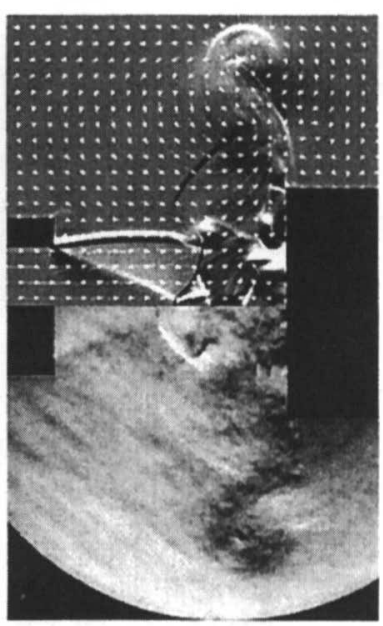

b) $300 \mu \mathrm{s}$
Fig.5 Numerical velocity vector and calculated and experimental Schlieren photograph $(\mathrm{Ms}=1.6 \mathrm{~L} / \mathrm{D}=2)$

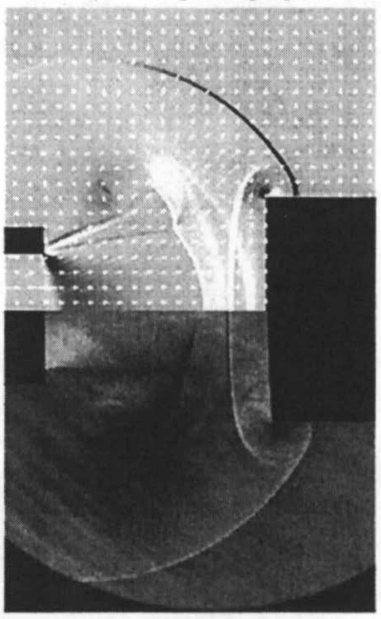

a) $30 \mu \mathrm{s}$

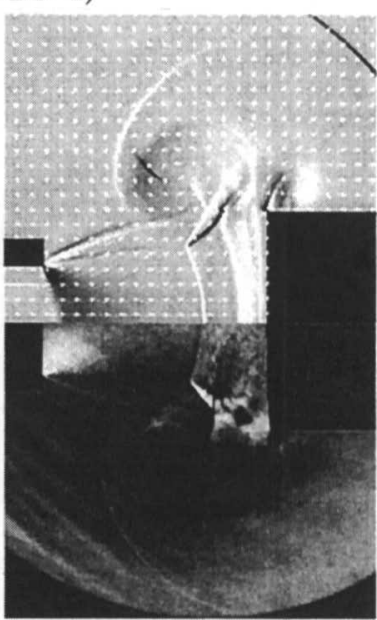

b) $100 \mu \mathrm{s}$
Fig.7 Numerical velocity vector and calculated and experimental Schlieren photograph $(\mathrm{Ms}=2.2 \mathrm{~L} / \mathrm{D}=2)$

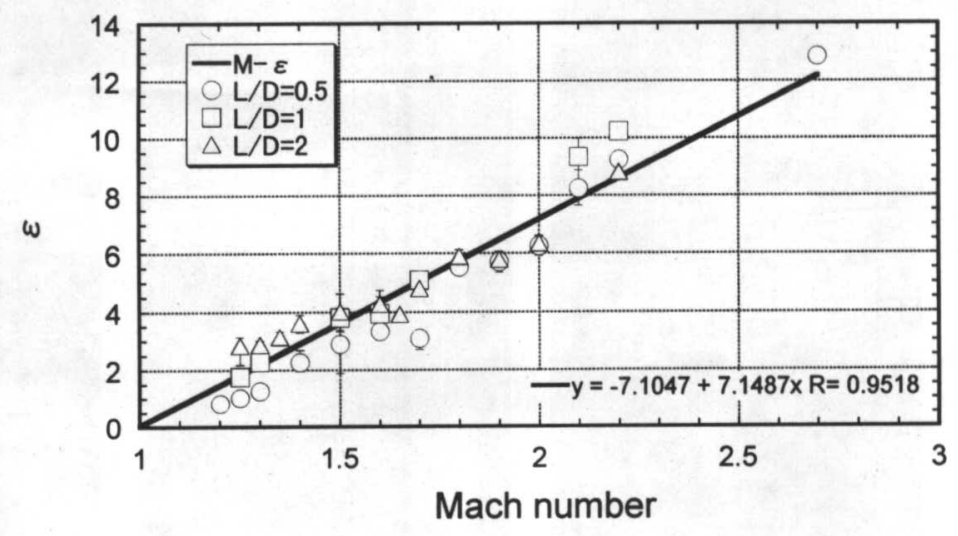

Fig.8 Relationship between $\varepsilon$ and Mach number 